Original Research Paper

\title{
Implementasi Metode the Student Group Dalam Upaya Meningkatkan Motivasi Belajar Siswa Pada Mata Pelajaran Pendidikan Agama Hindu dan Budi Pekerti Kelas XI di SMK Negeri 3 Mataram Tahun Pelajaran 2016/2017.
}

\author{
I Wayan Pica Parthayasa ${ }^{1}$ \\ ${ }^{1}$ Sekolah Menengah Kejuruan Negeri 3 Mataram, Indonesia.
}

*Corresponding Author:

I Wayan Pica Parthayasa,

Sekolah Menengah

Kejuruan Negeri 3

Mataram, Indonesia;

Email:

pica.parthayasa@gmail.com

\begin{abstract}
Abstrak: Tujuan penelitian ini adalah mengetahui apakah metode The Student Group dapat meningkatkan motivasi belajar siswa kelas XI di SMK Negeri 3 Mataram Tahun Pelajaran 2016/2017 pada mata pelajaran pendidikan Agama Hindu dan Budi Pekerti. Penelitian ini merupakan penelitian tindakan kelas dan dilakukan di Sekolah Menengah Kejuruan Negeri 3 Mataram. Analisis data dilakukan dengan mengumpulkan data prestasi belajar siswa kemudian dibandingkan dari nilai yang diproleh siswa dari refleksi awal, siklus I, dan siklus II. Dari nilai refleksi awal, nilai siklus I, nilai siklus II dibandingkan, dan dihitung peningkatanya untuk mengetahui tingkat keberhasilan pembelajaran the Student Group. Nilai KKM pelajaran Pendidikan Agama Hindu dan Budi Pekerti adalah 77. Apabila hasil post test yang diproleh masih berada di bawah nilai KKM maka masih perlu diadakan perbaikan, sedangkan apabila hasil post test yang diperoleh di atas nilai KKM, maka pembelajaran The Student Group perlu dilanjutkan dan disempurnakan. Hasil penelitian ini menunjukkan bahwa penerapan metode pembelajaran The Student group dapat meningkatkan motivasi belajar siswa kelas XI di SMK Negeri 3 Mataram pada mata pelajaran Pendidikan Agama Hindu dan Budi Pekerti yang dibuktikan dengan motivasi kelas berturut-turut $\mathbf{7 9 , 8 9}$ berkatagori" baik" pada siklus I dan $\mathbf{8 6 , 7 6}$ berkatagori "amat baik" pada siklus II. Hasil penelitian tersebut menunjukkan terjadinya peningkatan motivasi belajar sebesar 6,87 dari siklus I ke siklus II.
\end{abstract}

Kata Kunci: Motivasi Belajar, Metode The Student Group

\section{Pendahuluan}

Pendidikan merupakan hal yang sangat penting dalam kehidupan. Manusia membutuhkan pendidikan untuk dapat mengembangkan potensi dan kemampuan dalam upaya dalam mempertahankan hidup dalam bermasyarakat. Undang-Undang RI No. 20 Tahun 2003 tentang Sistem Pendidikan Nasional Pasal 1 ayat (1) yang menyatakan: "Pendidikan adalah usaha sadar dan terencana untuk mewujukan suasana belajar dan proses pembelajaran agar peserta didik secara aktif mengembangkan potensi dirinya untuk memiliki kekuatan spritual keagamaan, pengendalian diri, kepribadian, kecerdasan, akhlak mulia, serta keterampilan yang diperlukan dirinya, masyarakat, bangsa dan Negara".
Pendidikan Nasional yang berdasarkan Pancasila dan Undang-Undang Dasar Negara Republik Indonesia Tahun 1935 berfungsi mengembangkan kemampuan dan membentuk watak serta peradaban bangsa yang bermartabat dalam rangka mencerdaskan kehidupan bangsa, bertujuan untuk mengembangkan potensi peserta didik agar menjadi manusia yang beriman dan bertakwa kepada Tuhan Yang Maha Esa, berakhlak mulia, sehat, berilmu, cakap, kreatif, mandiri, dan menjadi warga negara yang demokratis serta bertanggung jawab.

Mata pelajaran pendidikan Agama Hindu dan Budi Pekerti adalah salah satu mata pelajaran yang didalamnya mencakup pelajaran memahami, menghayati dan juga mengamalkannya dalam kehidupan sehari-hari. Tetapi dalam kenyataan yang ada di lapangan mata pelajaran pendidikan 
Agama Hindu dan Budi Pekerti dewasa ini mutunya masih rendah karena belum mencapai target yang diingingkan secara memadai. Hal ini disebabkan karena kesulitan siswa dan juga memahami materi yang sukar diterima. Selain itu metode yang digunakan dalam proses belajar mengajar masih terpaku pada buku-buku pelajaran.

Pendidikan Agama Hindu dan Budi Pekerti menekankan pada pemberian pengalaman secara langsung. Siswa perlu dibantu untuk mengembangkan sejumlah ketrampilan supaya mereka mampu menjelajahi dan memahami alam sekitar. Ketrampilan proses ini meliputi keterampilan mengamati dengan seluruh indera, mengajukan hipotesis, menggunakan alat dan bahan dengan benar dan selalu memperhatikan keselamatan kerja, mengajukan pertanyaan, menggolongkan, menafsirkan data dan mengkomunikasikan hasil temuan secara beragam, menggali dan memilah informasi faktual yang relevan untuk menguji gagasan-gagasan dalam memecahkan masalah.

Kajian Agama Hindu yang begitu luas memerlukan pemilihan strategi pembelajaran atau metode pembelajaran yang tepat, agar dapat dengan mudah dipahami oleh siswa. Ilmu Agama Hindu yang materi pembelajarannya tidak dapat dipraktekan di laboratorium, memerlukan pemilihan metode pembelajaran yang tepat, sehingga pemahaman konsep, pemecahan masalah, katagorisasi dan resensi yang diperoleh dengan menggunakan usaha-usaha intensif melalui pengarahan dan pengawasan

Pada umumnya guru sering menggunakan satu metode dalam pengajaran, sehingga mengakibatkan proses belajar anak hanya bersifat harfiyah saja. Sedangkan untuk meningkatkan mutu pelajaran pendidikan banyak hal yang perlu dipertimbangkan diantaranya dalam hal penyampaian materi dari sumber pesan melalui metode tertentu merupakan kebijakan penerima pesan atau siswa. Sedangkan metode yang digunakan di sekolah masih kurang dapat menciptakan suasana yang kondusif, hal ini dapat menyebapkan siswa secara mental menganggap bahwa pendidikan Agama Hindu dan Budi Pekerti sebagai mata pelajaran yang sukar dipahami sehingga siswa kurang bergairah dalam belajar.

Masalah belajar pada hakekatnya adalah proses kearah terbentuknya tingkah laku yang baru. Perbuatan belajar dilakukan manusia sepanjang hidupnya secara terus menerus dan dilakukan berulang-ulang, sehingga terbentuklah kebiasaan belajar, melalui belajar manusia berusaha mengaktualkan potensi dirinya dan juga lingkungan secara optimal.

Belajar merupakan suatu proses yang ditandai dengan adanya perubahan pada diri sesorang, pembelajaran merupakan sebagaian dari proses belajar yang dapat ditujukan dalam berbagai bentuk, seperti perubahan pengetahuan, pemahaman sikap dan juga tingkah laku, ketrampilan, kecakapan, kebiasaan, serta merupakan aspek-aspek lain yang ada pada individu yang belajar (Erwinsyah, 2017).

Tingkah laku sebagai proses dari hasil belajar yang dipengaruhi oleh banyak faktor baik faktor yang berada dalam individu (faktor internal) maupun faktor yang berada dalam luar individu (faktor eksternal). Faktor internal adalah kemampuan yang dimiliki minat dan perhatiannya. Sedangkan faktor eksternal dalam proses pendidikan dan juga pengajaran dapat dibedakan menjadi tiga lingkungan, yaitu lingkungan keluarga, lingkungan sekolah, dan juga lingkungan masyarakat, kesemuanya ini sangat mempengaruhi proses belajar siswa dalam meningkatkan motivasi belajar siswa.

Motivasi berasal dari kata motif yang berarti dorongan yang terarah kepada pemenuhan psikis dan rokhaniah. Menurut Mc. Donald (Hamalik, 2011), motivasi adalah perubahan energi dalam diri (pribadi) seseorang yang ditandai dengan timbulnya perasaan dan reaksi untuk mencapai tujuan. Sedangkan menurut Sardiman (2010) dalam kegiatan belajar motivasi dapat dikatakan sebagai keseluruhan daya penggerak di dalam diri siswa yang menimbulkan kegiatan belajar, sehingga tujuan yang dikehendaki oleh subjek belajar itu dapat tercapai. Menurut Dalyono (2009) motivasi belajar adalah suatu daya penggerak atau dorongan yang dimiliki oleh manusia untuk melakukan suatu pekerjaan yaitu belajar. Menurut Hamzah (2011) hakikat motivasi belajar adalah dorongan internal dan eksternal pada siswa-siswa yang sedang belajar untuk mengadakan perubahan tingkah laku, pada umumnya dengan beberapa indikator atau unsur yang mendukung.

Dalam masalah belajar, motivasi belajar sangat penting karena motivasi merupakan syarat mutlak untuk belajar. Disekolah seringkali terdapat anak yang malas, tidak menyenangkan, suka bolos 
dan lain sebagainya. Dalam yang demikian berarti guru tidak berhasil memberikan motivasi yang tepat untuk mendorong agar ia bekerja dengan segenap tenaga dan juga pikirannya. Dalam hubungan ini perlu diingat bahwa anak itu bodoh terhadap pelajaran ini. Sering kali terjadi seorang anak yang malas terhadap suatu mata pelajaran tertentu akan tetapi sangat giat terhadap mata pelajaran lain.

\section{Metode}

Penelitian ini ini merupakan penelitian tindakan kelas yang lazim disebut claasroom action research. Rancangan model penelitian tindakan kelas ini adalah model spiral atau siklus dari Kemmis dan Taggart (1992) yaitu berbentuk spiral dari sklus yang satu ke siklus yang berikutnya. Setiap siklus meliputi planning (rencana), action (tindakan), observation (pengamatan), dan reflection (refleksi).

Siklus spiral dari tahap-tahap penelitian tindakan kelas dapat dilihat pada gambar berikut:

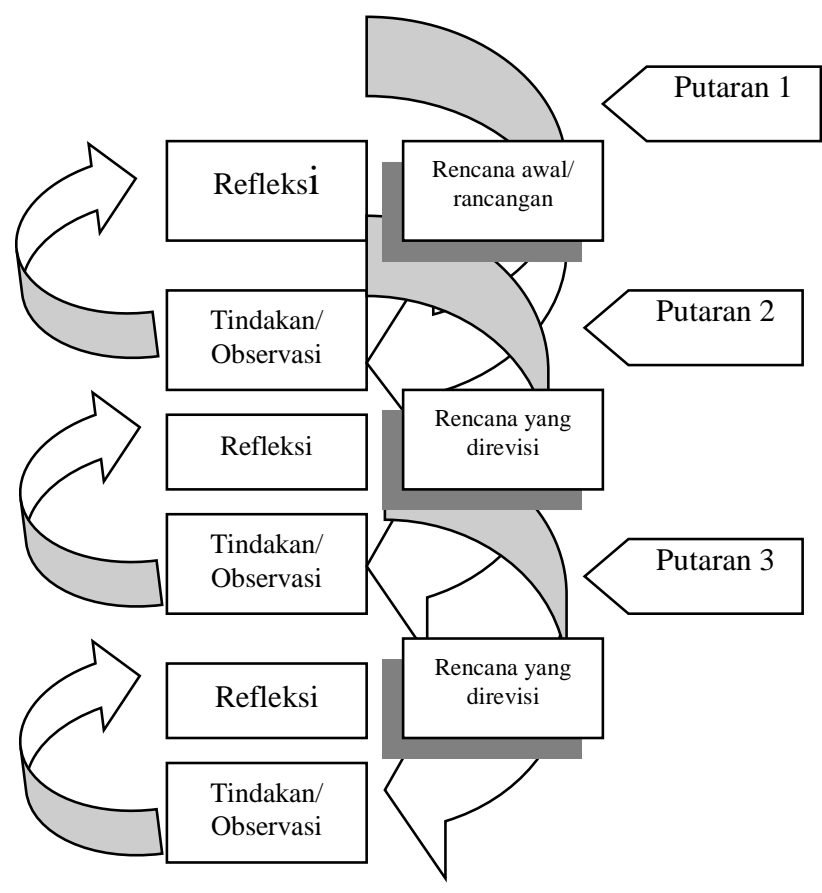

Gambar 1. Alur Penelitian Tindakan

Penelitian ini dilaksanakan di Sekolah Menengah Kejuruan Negeri 3 Mataram. Pemilihan lokasi ini disebabkan peneliti menjadi Guru di tempat ini. Dengan demikian, peneliti tahu kondisi nyata yang ada dilokasi penelitian. Di sekolah ini kegiatan pembelajaran Agama Hindu dominan menggunakan pembelajaran konvensional dan penugasan, sehingga kurang mencapai tujuan pembelajaran.

Analisis data dilakukan dengan mengumpulkan data prestasi belajar siswa kemudian dibandingkan dari nilai yang diproleh siswa dari refleksi awal, siklus I, dan siklus II. Dari nilai refleksi awal, nilai siklus I, nilai siklus II dibandingkan, dan dihitung peningkatanya untuk mengetahui tingkat keberhasilan pembelajaran the Student Group. Nilai KKM pelajaran Pendidikan Agama Hindu dan Budi Pekerti adalah 77. Apabila hasil post test yang diproleh masih berada di bawah nilai KKM maka masih perlu diadakan perbaikan, sedangkan apabila hasil post test yang diperoleh di atas nilai KKM, maka pembelajaran the Student Group perlu dilanjutkan dan disempurnakan.

Untuk menentukan keberhasilan penelitian tindakan kelas dapat dilihat dari perubahan skor rata-rata untuk masing-masing siklus. Apabila terjadi perubahan positif (makin tinggi) skor ratarata prestasi belajar dan motivasi belajar siswa dari refeksi awal ke siklus 1 dan ke siklus 2, dalam mengikuti proses pembelajaran The Student Group, maka berarti tindakan ini efektif dilakukan dalam rangka meningkatkan prestasi belajar Pendidikan Agama Hindu dan Budi Pekerti kelas XI Sekolah Menengah Kejuruan Negeri 3 Mataram tahun 2016/2017.

\section{Hasil dan Pembahasan}

Proses pembelajaran dengan penerapan pembelajaran the Student Group berlangsung 2 siklus, masing-masing siklus terdiri dari tahapantahapan, yaitu: tahap perencanaan, tindakan, diagnosis/observasi dan tahap refleksi/evaluasi. Berdasarkan implementasi siklus diperoleh data sebagai berikut:

\section{Siklus Pertama}

Kajian ilmu Agama Hindu yang begitu luas memerlukan pemilihan strategi pembelajaran atau metode pembelajaran yang tepat, agar dapat dengan mudah dipahami oleh siswa. Selama ini guru-guru yang mengajar mata pelajaran di Sekolah Menengah Kejuruan Negeri 3 Mataram termasuk 
pelajaran Pendidikan Agama Hindu dan Budi Pekerti kebanyakan menggunakan metode ceramah, penugasan, dan yang lainnya, sehingga membosankan siswa.

Dengan kondisi seperti yang dipaparkan di atas, berpengaruh terhadap prestasi belajar siswa pada mata pelajaran Pendidikan Agama Hindu siswa SMK Negeri 3 Mataram. Kreteria ketuntasan minimal di SMK Negeri 3 Mataram untuk kompetensi dasar materi ini adalah 77. Rata-rata hasil pre test sebagai kondisi awal pada kelas sebelum dilakukan tindakan untuk materi pembelajaran yang sama sebesar 70,68 yang masih dibawah kriteria ketuntasan minimal yang ditetapkan sekolah. Secara klasikal siswa siswa memiliki nilai pre test di bawah standar yang ditetapkan sekolah sebanyak $80 \%$. Pada refleksi awal peneliti juga mengumpulkan atau mencari informasi dari guru lain yang mengajar siswa kelas XI Semua Jurusan.

Pelaksanaan siklus I dilaksanakan dalam 3 kali pertemuan, yaitu pertemuan I dilaksanakan pada tanggal 24 Oktober 2017, pertemuan II dilaksanakan pada tanggal 25 Oktober 2017, dan pertemuan III dilaksanakan pada tanggal 26 Oktober 2017 dengan materi Yoga Menurut Agama Hindu.

\section{Pertemuan I}

Diawali dengan pembukaan, selanjutnya melakukan apersepsi, kemudian penyampaian tujuan pembelajaran. Dilanjutkan pembentukan kelompok asal,kelompok ahli, pembagian 5 jenis LKS berbeda, dengan materi: (1) Mengenal dan Manfaat Ajaran Yoga, (2) Astangga Yoga, (3) Panca Yama Bratha, (4) Panca Nyama Bratha, (5) Etika Yoga. Dilanjutkan dengan diskusi kelompok ahli,diskusi kelompok asal/awal, serta diskusi kelas. Pada akhir pertemuan dibuat kesimpulan tentang materi yang dibahas.

\section{Pertemuan II}

Diawali dengan pembukaan dengan apersepsi, serta penyampaian tujuan pembelajaran. Pada kegiatan inti guru membagikan 5 jenis LKS yang berbeda dengan materi:(1) Panca Yama Bratha, (2) Panca Nyama Bratha, (3) Astangga Yoga, (4) Etika Yoga (5) Sjarah Yoga. Selanjutnya siswa berdiskusi dalam kelompok ahli untuk memecahkan masalah. Setelah selesai berdiskusi dalam kelompok ahli,maka masing-masing anggota kelompok ahli kembali ke kelompok asal untuk mensosialisasikan jawaban kepada anggota kelompok asalnya. Kemudian dilanjutkan dengan pelaporan hasil diskusi/diskusi kelas.Selama pelaksanaan diskusi, guru mengamati dan membimbing siswa dalam berdiskusi agar terarah dan efektif. Guru memberi penguatan atau pujian berupa applus kepada kelompok siswa yang sudah bekerja dengan baik. Pada akhir kegiatan guru bersama siswa menyimpulkan hasil diskusi.

\section{Pertemuan III}

Semua siswa mengukuti post tes secara individu, Guru memeriksa hasil pekerjaan siswa yang dilanjutkan dengan penskoran nilai perkembangan individu dan skor kelompok, serta memberikan penghargaan kepada kelompok yang memperoleh nilai terbaik. Sebagai langkah penutup guru menyarankan kepada siswa untuk berani mengemukakan pendapat serta dapat bekerja sama dalam kelompoknya guna meningkatkan prestasi belajar.

Berdasarkan hasil tes dan penskoran pada nilai individu dan nilai kelompok pada siklus I, maka diperoleh nilai rata-rata kelas sebesar 78,76 yaitu pada katagori "baik" dan Ketuntasan klasikal naik $53 \%$ dari $20 \%$ pada refleksi awal menjadi $73 \%$. Daya serap siswa naik 8,08 dari 70,68 pada refleksi awal menjadi 78,76 pada siklus I. Kriteria prestasi belajar pada siklus I dapat dilihat pada Tabel 1.

Tabel1. Kriteria Prestasi Belajar Siklus I

\begin{tabular}{clll}
\hline No & Klas Interval & Frekwensi & \multicolumn{1}{c}{ Kategori } \\
\hline 1 & $<70,00$ & 2 orang & Sangat Kurang \\
\hline 2 & $70,00-73,34$ & 2 orang & Kurang \\
\hline 3 & $73,34-76,67$ & 4 orang & Sedang \\
\hline 4 & $76,67-80,00$ & 24 orang & Baik \\
\hline 5 & $>80,00$ & 5 orang & Amat Baik \\
\hline
\end{tabular}

Berdasarkan hasil kuisioner tentang motivasi belajar siswa diperoleh rata-rata sebesar 79,89 dengan katagori "baik". Data hasil kuesioner tentang motivasi belajar siswa dijelaskan pada Tabel 2.

Tabel 2. Kriteria Motivasi Belajar Pada Siklus I

\begin{tabular}{llll}
\hline No & Interval & Frekw. & Katagori \\
\hline 1 & Kurang dari 74,00 & 3 orang & Sangat Kurang \\
2 & $74,00-76,67$ & 4 orang & Kurang \\
3 & $76,67-79,34$ & 7 orang & Sedang \\
4 & $79,34-82,00$ & 19 orang & Baik \\
5 & Lebih dari 82,00 & 7 orang & Amat Baik \\
\hline
\end{tabular}




\section{Siklus Kedua}

Tahap pelaksanaan siklus II sama dengan siklus I, akan tetapi pada siklus II dilakukan perbaikan-perbaikan berdasarkan refleksi I. Siklus II dilaksanakan dalam 3 kali, yaitu pertemuan I pada tanggal 7 Nopember 2017, pertemuan II pada tanggal 8 Nopember 2016 dan pertemuan III pada tanggal 9 Nopember 2017 dengan materi Etika Yoga dengan contoh pada Gerakan Yoga Asanas dan Manfaat, serta Penjelasan masingn-masing jenis Gerakan Yoga Asanas.

\section{Pertemuan I}

Pertemuan I dawali dengan apersepsi dan penyampaian tujuan pembelajaran. Dilanjutkan dengan pembagian 5 jenis LKS berbeda yang materi: (1) Gerakan Yoga Asanas , (2) Manfaat, (3) Penjelasan Padmasana,(4) Penjelasan Swastikasana, (5) Penjelasan Sarwangasana. Kemudian dilanjutkan dengan diskusi kelompok ahli, diskusi kelompok asal/awal, serta pelaporan hasil diskusi dalam diskusi kelas. Pada akhir pertemuan dibuat kesimpulan tentang materi yang dibahas.

\section{Pertemuan II}

Diawali dengan pembukaan dengan apersepsi, serta penyampaian tujuan pembelajaran. Pada kegiatan inti guru membagikan 5 jenis LKS yang berbeda dengan materi: (1)Gerakan Yoga Asanas,(2) Manfaat Yoga Asanas, (3) Penjelasan Padmasana,(4) Penjelasan Swastikasana , (5) Penjelasan Sarwasana. Selanjutnya siswa berdiskusi dalam kelompok ahli untuk memecahkan masalah. Setelah selesai berdiskusi dalam kelompok ahli, maka masing-masing anggota kelompok ahli kembali ke kelompok asal untuk mensosialisasikan jawaban kepada anggota kelompok asalnya. Kemudian dilanjutkan dengan pelaporan hasil diskusi dalam diskusi kelas.Selama terjadi diskusi, guru mengamati dan membimbing siswa agar diskusi efektif dan terarah. Guru memberi pujian kepada kelompok siswa yang sudah bekerja dengan baik. Pada akhir kegiatan guru bersama siswa menyimpulkan hasil diskusi.

\section{Pertemuan III}

Pada pertemuan ini siswa mengerjakan post tes sendiri-sendiri, Setelah selesai guru memeriksa pekerjaan siswa. Dilanjutkan dengan penskoran nilai perkembangan individu dan skor kelompok, serta memberikan penghargaan kepada kelompok yang nilainya paling baik. Sebagai langkah penutup guru menyarankan siswa untuk berani mengemukakan pendapat serta dapat bekerja sama dalam kelompoknya guna meningkatkan prestasi belajar.

Dari hasil tes yang dikumpulkan diproleh nilai rata-rata kelas 89,05 yaitu pada katagori "amat baik" dan ketuntasan klasikal (KK) 92,00\% . Ini berarti nilai rata-rata kelas naik 4,07 dan KK naik $92 \%$ dari siklus I. Hasil prestasi belajar pada siklus II tertera pada tabel 3.

Tabel 3. Profil Prestasi Belajar Siklus II

\begin{tabular}{llll}
\hline No & Klas Interval & Frekwensi & Kategori \\
\hline 1 & $<76,25$ & 4 orang & Sangat Kurang \\
2 & $76,25-80,42$ & 0 orang & Kurang \\
3 & $80,42-84,59$ & 2 orang & Sedang \\
4 & $84,59-88,76$ & 7 orang & Baik \\
5 & $>88,76$ & 27 orang & Amat Baik \\
\hline
\end{tabular}

Berdasarkan hasil kuisioner tentang motivasi belajar siswa, maka diperoleh data pada Tabel 4: Tabel 4.6 Kriteria Motivasi Belajar pada Siklus II

\begin{tabular}{llll}
\hline No & Interval & Frekw. & Katagori \\
\hline 1 & Kurang dari 74,00 & 0 orang & Sangat Kurang \\
2 & $74,00-76,67$ & 1 orang & Kurang \\
3 & $76,67-79,34$ & 4 orang & Sedang \\
4 & $79,34-82,00$ & 10 orang & Baik \\
5 & Lebih dari 82,00 & 23 orang & Amat Baik \\
\hline
\end{tabular}

Kegiatan belajar mengajar pada siklus II berjalan dengan baik. Semua anggota kelompok aktif dan bergairah dengan suasana kelas dan pembelajaran tampak menyenangkan. Rata-rata motivasi belajar siswa pada siklus kedua sebesar 86,76 berada pada katagori "amat baik". Nilai ratarata kelas mengalami peningkatan dari 78,76 pada siklus I menjadi 89,05 pada siklus II. Ketuntasan klasikal naik $19 \%$, yaitu dari $73 \%$ pada siklus I menjadi $92,00 \%$ pada siklus II. Meskipun ketuntasan klasikal tidak dapat naik $100 \%$, peneliti memandang perlu menerapkan pembelajaran the Student Group karena pembelajaran ini dapat meningkatkan motivasi dan prestasi belajar siswa.

\section{Kesimpulan}

Berdasarkan hasil tindakan kelas yang dilakukan dapat disimpulkan bahwa penerapan 
metode the Student Group dapat meningkatkan motivasi belajar siswa kelas XI di SMK Negeri 3 Mataram Tahun Pelajaran 2016/2017 pada mata pelajaran pendidikan Agama Hindu dan Budi Pekerti. Hal ini ditunjukkan dengan nilai rata-rata kelas mengalami peningkatan dari 78,76 pada siklus I menjadi 89,05 pada siklus II. Ketuntasan klasikal naik $19 \%$, yaitu dari $73 \%$ pada siklus I menjadi $92,00 \%$ pada siklus II.

\section{Saran}

Berdasarkan hasil penelitian maka disarankan kepada guru untuk menerapkan metode pembelajaran the Student Group untuk meningkatkan motivasi belajar siswa pada kelas dan mata pelajaran yang lain, karena dengan metode ini motivasi dan prestasi belajar siswa dapat ditingkatkan.

\section{Daftar Pustaka}

Dalyono, M. 2009. Psikologi Pendidikan. Jakarta. PT Rineka Cipta.

Erwinsyah, A. 2017. Manajemen Kelas dalam Meningkatkan Efektifitas Proses Belajar Mengajar. TADBIR: Jurnal Manajemen Pendidikan Islam. 5(2).

Hamalik, O. 2013. Proses Belajar Mengajar. Jakarta: PT.Bumi Aksara.

Hamalik, Oemar. 2011. Kurikulum Dan Pembelajaran. Jakarta. PT. Bumi Aksara.

Hamzah, B.Uno. 2011. Model pembelajaran (menciptakan proses belajar yang kreatif dan efektif). Jakarta. PT.Bumi Aksara.

Kemmis, S \& Mc Taggart, R. 1992.The Action Research Planner. Australia. Deakin University Pres.

Sardiman. 2010. Interaksi dan Motivasi Belajar Mengajar.Jakarta. PT.Raja Grafindo Persada. 